\title{
Article \\ Strength and Compressibility of Ammonia-Soda Residue from the Solvay Sodium Plant
}

\author{
Jakub Zięba ${ }^{1}$, Przemysław Rzepka ${ }^{2,3}$ [D and Bartłomiej Szczepan Olek ${ }^{1, *}$ \\ 1 Department of Geotechnics and Strength of Materials, Cracow University of Technology, ul. Warszawska 24, \\ 31-155 Kraków, Poland; jakub.zieba@pk.edu.pl \\ 2 Institute for Chemistry and Bioengineering, ETH Zurich, 8093 Zurich, Switzerland; \\ przemyslaw.rzepka@chem.ethz.ch \\ 3 Laboratory for Catalysis and Sustainable Chemistry, Paul Scherrer Institute, 5232 Villigen, Switzerland \\ * Correspondence: bartlomiej.olek@pk.edu.pl; Tel.: +48-609068216
}

check for

updates

Citation: Zięba, J.; Rzepka, P.; Olek, B.S. Strength and Compressibility of Ammonia-Soda Residue from the Solvay Sodium Plant. Appl. Sci. 2021, 11, 11305. https://doi.org/10.3390/ app112311305

Academic Editors: Daniel Dias,

Małgorzata Jastrzębska,

Krystyna Kazimierowicz-

Frankowska, Gabriele Chiaro and Jaroslaw Rybak

Received: 7 October 2021

Accepted: 26 November 2021

Published: 29 November 2021

Publisher's Note: MDPI stays neutra with regard to jurisdictional claims in published maps and institutional affiliations.

Copyright: (C) 2021 by the authors. Licensee MDPI, Basel, Switzerland. This article is an open access article distributed under the terms and conditions of the Creative Commons Attribution (CC BY) license (https:// creativecommons.org/licenses/by/ $4.0 /)$.

\begin{abstract}
This work presents the discussion of the results for an experimental study conducted to characterise the mechanical behaviour of ammonia-soda residue (ASR). The calcareous sludge is an alkaline waste formed during the production of soda ash and deposited at the area of the former Solvay Sodium Plant factory in Krakow, Poland. Isotropically consolidation drained (CID) triaxial tests and constant rate of strain (CRS) consolidation tests include the full saturation with water, completion of the consolidation, and the loading/strain rate choice. For this purpose, ASR undisturbed samples were collected from the ground and submitted to laboratory experiments. These samples show a distinct difference in the initial bulk density, the initial level of compaction, initial void ratio, and the natural water content. The $\mathrm{CD}$ triaxial tests were conducted under three different levels of confining pressure; in turn, CRS tests were run with two appropriate input strain rates. According to the physical state of ASR and the depth of sampling, two different evolutions of the critical state in the stress-strain space were observed. In the light of the assessed stress-strain-strength behaviour, key design engineering parameters of ASR were calculated.
\end{abstract}

Keywords: ammonia-soda residue; compressibility; constant rate of strain; drained; shear strength; triaxial test

\section{Introduction}

Ammonia-soda residue (ASR), also known as ammonia-soda white mud or ammoniasoda ash waste, is an alkaline calcareous sludge formed during the production of industrial soda ash (SA) (Solvay processes). ASR is a white-coloured fine-grained material commonly stored in landfills or settling ponds and may be potentially hazardous and negatively impacting natural and human systems. SA (sodium carbonate, $\mathrm{Na}_{2} \mathrm{CO}_{3}$ ) is an essential inorganic product that has several diversified applications in the chemical industry [1-3], metallurgy [4,5], textile [6,7], printing and dyeing [8], glass [9-11], medicine [12], and food industries $[13,14]$. SA is also exploited in geotechnics to stabilise the subgrade soft soil, improve the geotechnical properties of soil, and accelerate the hardening of soil-binder mixtures.

In 2020, the total global production of soda ash was estimated to be about 52 million metric tons [15], with a considerable amount of ASR as a by-product material from manufacturing. The ASR is usually slurry-deposited and exhibits a unique structure with high moisture content, high compressibility, and unusual geotechnical properties [16,17], which presented several challenges to the capping landfill design [18,19]. Another feature is the fact that the ASR consists of extremely fine particles with a large specific surface area that exhibits a strong adsorption capacity [20,21]. Coleman et al. [22] considered SA as an additive to soil-cement mixtures to determine its effect on soil-cement and soilcement-fly ash strength properties. It was found that the beneficial effects of the addition of 
0.5 wt.\% sodium carbonate were most observed after short curing periods. Over a longer time, SA can be detrimental to mixtures containing low cement contents. However, the authors reported various effects of addition of SA on the strengths of the soil-cement and soil-cement-fly ash mixtures.

El-Rawi and Toma [23] reported that sodium hydroxide and carbonate were effectively used as chemical additives with Iraqi soils stabilised by cement to increase shear strength.

Sun et al. [24] studied the engineering properties of the solidified soil with $20 \%$ nonclinker incorporating soda residue curing agent. The strength properties of this sample were almost the same as that of the solidified soil with about $10 \%$ composite cement. Zha et al. [25] examined alkaline residue as a new binder to treat heavy metal-contaminated soil because of its strong adsorption capacity for heavy metal ions. The increase of the treated soil's unconfined compressive strength (UCS) was associated with the drop of the leached $\mathrm{Pb}^{2+}$ concentration and the rise of the alkaline residue content in the specimen. He et al. [26] investigated the shear strength properties of stabilised soft soil composed of ASR and ground granulated blast furnace slag and compared it to cement-stabilised soil in deep mixing and soil-cement columns.

Nazir et al. [27] studied the effect of SA on $\mathrm{pH}$ and the compaction characteristics of Malaysian laterite soil. Based on the experimental investigation, the addition of soda ash led to the increase of $\mathrm{pH}$ of the soil and improvement of the compaction properties. Han et al. [28] used calcium chloride and SA solutions to decrease the soil expansion potential. The reduction in the expansion parameters was primarily attributed to the strong short-term reactions between clay and stabilisers.

Bai et al. [29] considered the improvement of ASR properties by using liquid soda residue and liquid fly ash. Mixing ASR and fly ash resulted in the elevation of the water content, liquid limit, and plastic limit, and lowering of permeability and compressibility in the pretreated soil. Furthermore, potential benefits of the exploitation of SA for the preparation of ASR were assessed through laboratory and field tests. The field tests on ASR were also carried out by Ma et al. [30] to study the impact of gravel, sand, and lime on the mechanical properties of ASR. The authors indicated that the addition of fly ash contributes to the enhancement of the strength properties of ASR, and the lime, sand, and rubble have a significant effect on the subgrade bearing capacity of composite soils consisting ASR.

Wang et al. [31] showed the safety risks associated with the use of ASR. Their analysis supported previous findings on the use of ASR in the cement industry [32-36] and suggested that ASR without any pretreatment for reducing harmful pollutants and/or stabilisation [37] should not be considered for soil remediation or agricultural activities. Based on the findings mentioned above, this statement also seems to hold true for geotechnical works.

As discussed above, numerous examples of using SA and ASR in geotechnical applications have been attempted. Reclamation activities have been conducted in the "White seas" area since 2006 to develop the land for a John Paul II Centre, roads, and tunnel facilities. Ground investigations were carried out at the site by Politechnika Krakowska to evaluate the impact of the earthworks on the behaviour of the anthropogenic sediments. Thus, broad research is needed to assess the strength and compressibility of the ASR properly. The main motivation for undertaking this study was the lack of available strength and compression data for this type of anthropogenic material. The general objective of the performed research was to conduct an appropriate experimental testing programme and to derive necessary parameters that characterise ASR properties. In order to analyse future tunnel-soil-structure systems, a long-term stability problem was assumed. Due to hydrogeologic conditions at the site, the drainage of the ASR during consolidation and shearing was expected. Therefore, it was decided to perform a CD-type triaxial test. An inclination of the critical state line along the stress-strain behaviour was of prime interest in the analysis. The results of the mechanical parameters were referred to the mineral composition and microstructure characterisation provided. 


\section{Experimental Procedure}

\subsection{Materials}

Material for the laboratory experiments was collected from the area of the Solvay Sodium Plant in Krakow. The subsoil contains Quaternary soils (sand and gravel interlayered by cohesive soils represented mainly by silt and mixtures of silt and clay), which lie directly on the Tertiary formations of the Miocene clays facies. Over the years, post-industrial waste has been deposited over the layers of natural soils.

The undisturbed samples of ASR were collected from a depth of ca. 7.5 and $16.5 \mathrm{~m}$ below the ground surface using a combined Shelby probe with the plastic insert. The high in situ water content in the analysed ASR up to $15 \mathrm{~m}$ below the sea level, i.e., around 200\%, led to large deformations even at low pressures. When the standard probe is used for a sample extrusion, a significant consolidation can occur, and a substantial loss of water from the soil is usually observed. Therefore, the sample with an undisturbed structure was collected by combining the Shelby probe with a plastic insert. The probe with an exterior diameter of $80 \mathrm{~mm}$ was selected, which allowed for installing a plastic pipe with a diameter of $75 \mathrm{~mm}$. The interior diameter of the probe was $71 \mathrm{~mm}$. The thicker sampler wall, made of the steel and PE pipes, allowed adjustment of the cutting knife to avoid large deformations of the taken sample. A cylinder was attached to the probe to provide accurate sampling for the ASR with a natural structure. The vacuum was applied during the extraction of the probe to the borehole in the sampler. The Pagani static probe was used to push the probe to a specific depth of sampling.

The groundwater table (GWT) was found at $15 \mathrm{~m}$ below sea level. Figure 1 shows the results of the piezocone test (CPTU) at the site. As one can see, the geotechnical profile consists of two anthropogenic layers of ASR lined by stiff clay. From the trend of cone resistance $\left(q_{t}\right)$ and pore water pressure measured behind the cone tip $\left(u_{2}\right)$ (both parameters increase with depth), the deposit of ASR is considered normally consolidated. The natural water content of the ASR I and ASR II varies from $150 \%$ to $200 \%$ and from $38 \%$ to $56 \%$, respectively.

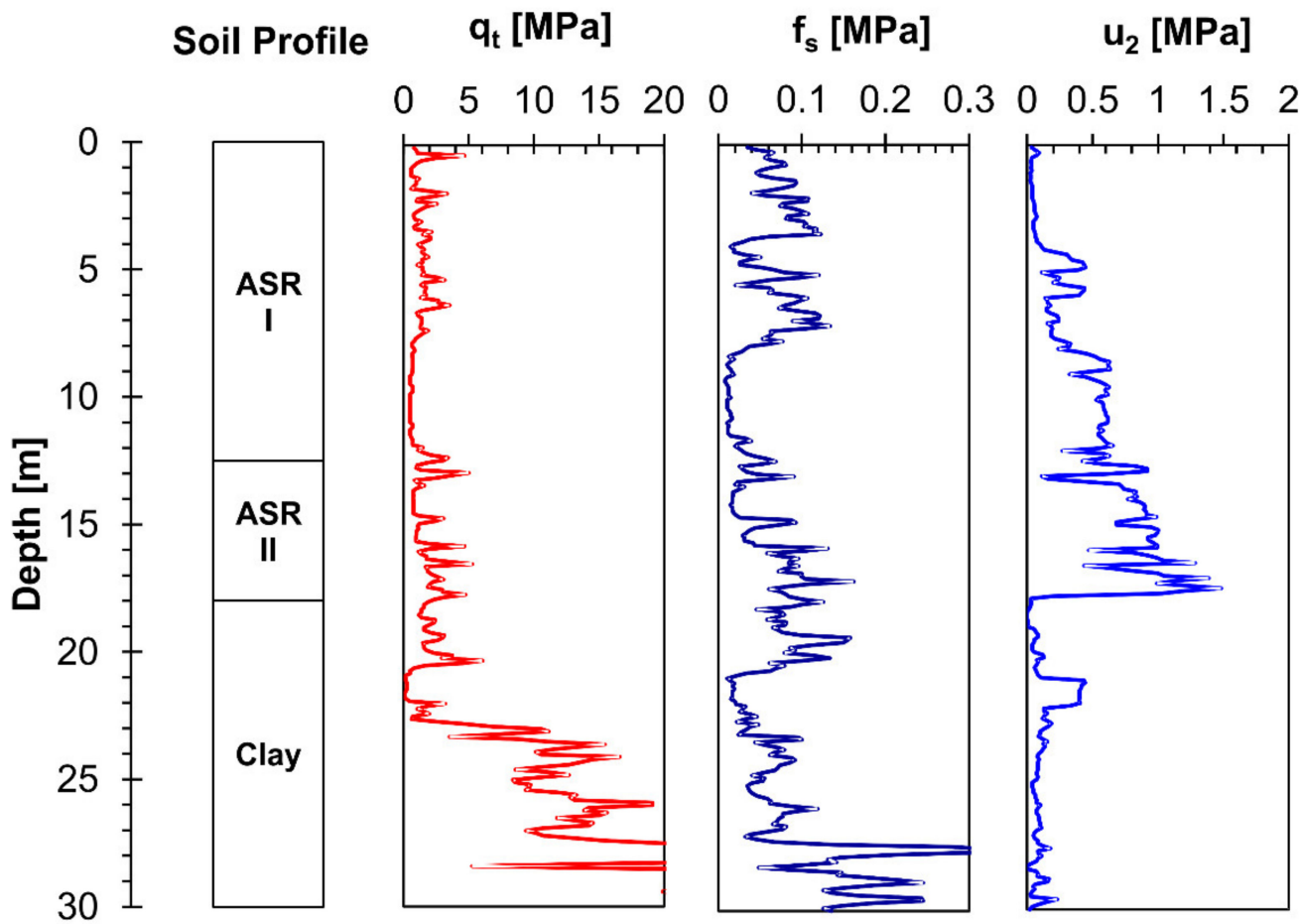

Figure 1. Soil profile with the piezocone test results. 


\subsection{Test Methods}

Powder X-ray diffraction (XRD) and scanning electron microscopy (SEM) analyses were used to identify the mineral composition of waste material and to investigate the microstructure of ASR. The specimen was dried under $105^{\circ} \mathrm{C}$. The $1-2 \mathrm{~cm}$ grey inclusions inside the white cement were recognised and separated for the phase and elemental analyses. Two X-ray diffraction patterns on both samples were collected at Bragg-Brentano geometry by using an in-house PANalytical X'Pert PRO MPD diffractometer and exploitation of monochromatic $X$-ray radiation of $\lambda=1.5406 \AA$. The data was recorded with step $0.08^{\circ}$ in a range of $5-90^{\circ}$. The phase identification was performed using $X^{\prime}$ Pert High Score Plus.

The SEM images and elemental analyses were obtained using a JEOL JSM-7100F scanning electron microscope and an EDAX "Octane Pro" SDD Energy Dispersive X-Ray Spectrometer. Thin layers of both samples were spread on top of aluminium stumps covered by carbon tape. The SEM images and EDS spectra were taken at $15.0 \mathrm{keV}$ with a working distance of $10.0 \mathrm{~mm}$. For imaging, the samples were additionally coated by a $10 \mathrm{~nm}$ layer of carbon.

The physical properties of the ASR were determined as per the relevant International Organization for Standardization (ISO). The conventional grain size analysis was conducted in accordance with ISO 17892-4 standard [38], and the density of soil skeleton $\left(\mathrm{G}_{\mathrm{s}}\right)$ was determined using the pycnometric method as per ISO 17892-3 [39]. The isotropically consolidated drained triaxial compression tests (CID) were carried out using the VJ-Tech triaxial compression apparatus. An appropriate testing procedure was adopted to gather high-quality data by performing full saturation with water, including increases of backpressure, consolidation, and the choice of the loading rate.

The samples with dimensions: diameter $50 \mathrm{~mm}$ and height $90 \mathrm{~mm}$ were formed. The height was measured before each test. The samples placed in the cell were sealed with airtight membranes and double O-rings. The porous disks and the paper filters were placed at the bottom and the top of the sample, ensuring the free water flow. The saturation of the specimens was done by the ramp method. In this technique, the cell pressure and back-pressure at the specimen's faces are ramped, and the B-check is performed at regular intervals to examine whether the required Skempton's pore pressure coefficient $\mathrm{B}$ (B-parameter) has been reached. The B-parameter was calculated as the ratio of the increase in the excess pore water pressure to the applied stress increment. A mean total stress increment of $50 \mathrm{kPa}$ was selected for all the B-checks. The ASR specimen was assumed to be saturated if the B-value was sufficiently high (the analysis criterion of B $>0.98$ was expected).

To achieve the isotropic consolidation stage, the confining pressure on both end faces of the specimen was applied for one hour to establish target effective stresses between 50 and $400 \mathrm{kPa}$. For all the tests, the time needed to complete dissipation did not exceed $2 \mathrm{~h}$.

The shearing and consolidation stages were carried out using one-way drainage conditions. The final loading rate was estimated to be ca. $50 \%$ of the maximum rate determined based on the consolidation results. Adopting such a rate limit results from the previous preliminary study [40].

The constant rate of strain (CRS) consolidation tests were performed in a MultiPurpose Consolidation Cell (MPCC) produced by VJ-Tech. In the CRS test, the load increases continuously while a constant strain rate remains constant, so the continuous recording of stresses and strains can be made. The most important parameter that must be determined before starting the CRS test is the strain rate [41,42]. If the strain rate is too low, the pore pressure is very small or not generated at all during the test, leading to erroneous values of hydraulic conductivity $\left(\mathrm{k}_{\mathrm{v}}\right)$ and coefficient of consolidation $\left(\mathrm{c}_{\mathrm{V}}\right)$. On the other hand, if the strain rate is too high, the determined value of preconsolidation stress is significantly overestimated. Since the first use of the CRS test, many different methods have been developed to determine the appropriate strain rate. In this work, the method of Ozer et al. [43] was adopted as the reference strain rate, which is based on comparing 
the results of the CRS test with the results of the reference oedometer study. Thus, one reference oedometer test with unloading and reloading of the samples was performed. In this case, the following scheme was conducted: load-unload-repeated load: $1 \rightarrow 6.25 \rightarrow$ $12.5 \rightarrow 25 \rightarrow 50 \rightarrow 100 \rightarrow 200 \rightarrow 400 \leftarrow 200 \leftarrow 100 \leftarrow 50 \leftarrow 25 \leftarrow 12.5 \rightarrow 25 \rightarrow 50 \rightarrow 100$ $\rightarrow 200 \rightarrow 400 \rightarrow 800 \rightarrow 1000 \mathrm{kPa}$.

\section{Results and Discussion}

\subsection{Physical Properties}

The grain size analysis showed that a silt fraction $(2-63 \mu \mathrm{mm})$ is a dominant component. In terms of consistency, the tested material revealed a soft-plastic state with liquidity index, $\mathrm{LI}=0.64$. Above the GWT, the ASR bulk density $(\rho)$ ranged from 1.15 to $1.19 \mathrm{~g} / \mathrm{cm}^{3}$ (on average $1.17 \mathrm{~g} / \mathrm{cm}^{3}$ ), and below the GWT, from 1.58 to $1.68 \mathrm{~g} / \mathrm{cm}^{3}$ (on average $\left.1.65 \mathrm{~g} / \mathrm{cm}^{3}\right)$. The pycnometric method indicated the density of the soil skeleton ranged from 2.58 to 2.62 (on average 2.60). The physical properties and test conditions of the specimens are summarised in Table 1.

Table 1. Physical properties and test conditions for triaxial drained tests.

\begin{tabular}{|c|c|c|c|c|c|c|}
\hline & Confining Pressure & $\mathrm{G}_{\mathrm{s}}$ & $\mathbf{n}$ & e & $S$ & Loading Rate \\
\hline & {$[\mathrm{kPa}]$} & {$[-]$} & {$[-]$} & {$[-]$} & {$[-]$} & {$[\mathrm{mm} / \mathrm{min}]$} \\
\hline \multirow{6}{*}{ ASR I } & 75 & 2.61 & 0.84 & 5.32 & 0.98 & 0.01 \\
\hline & 100 & 2.61 & 0.84 & 5.26 & 1.00 & 0.01 \\
\hline & 200 & 2.61 & 0.83 & 5.00 & 0.98 & 0.008 \\
\hline & 250 & 2.61 & 0.84 & 5.28 & 0.99 & 0.008 \\
\hline & 400 & 2.61 & 0.85 & 5.51 & 0.99 & 0.008 \\
\hline & 500 & 2.61 & 0.84 & 5.81 & 0.98 & 0.01 \\
\hline \multirow{6}{*}{ ASR II } & 75 & 2.60 & 0.55 & 1.24 & 1.00 & 0.01 \\
\hline & 100 & 2.60 & 0.56 & 1.28 & 1.00 & 0.01 \\
\hline & 200 & 2.60 & 0.58 & 1.36 & 1.00 & 0.01 \\
\hline & 250 & 2.60 & 0.58 & 1.38 & 1.00 & 0.012 \\
\hline & 400 & 2.60 & 0.58 & 1.40 & 1.00 & 0.015 \\
\hline & 500 & 2.60 & 0.57 & 1.32 & 1.00 & 0.015 \\
\hline
\end{tabular}

Note that: $\mathrm{G}_{\mathrm{s}}$-specific gravity, $\mathrm{n}-$ porosity, $\mathrm{e}-$ void ratio, $\mathrm{S}-$ degree of saturation.

\subsection{XRD and Microstructural Analysis}

The mineral composition of ASR was investigated by means of X-ray diffraction. The results are demonstrated in Figure 2. The phase analysis was based on the two diffractograms collected from the white cement, which is the major phase and the minor grey inclusions of 1-2 cm size. Both diffractograms show the distinct Bragg peaks, suggesting highly crystalline material. The phase analysis of the white cement revealed $57 \mathrm{wt} \%$ of calcite $\left(\mathrm{CaCO}_{3}\right), 31 \mathrm{wt} \%$ of portlandite $\left(\mathrm{Ca}(\mathrm{OH})_{2}\right), 7 \mathrm{wt} \%$ of brucite $\left(\mathrm{Mg}(\mathrm{OH})_{2}\right)$, and $5 \mathrm{wt} \%$ of barite $\left(\mathrm{BaSO}_{4}\right)$. The occurrence of barite results from Solvay production of barium carbonate, which was manufactured from natural barium sulfate. The grey inclusions were found as composed of mostly still calcite $(83 \%)$ but associated with gypsum $(8 \mathrm{wt} \%)$ and analcime $(7 \mathrm{wt} \%)$. The formation of analcime rose from the highly alkaline environment provided by soda wastes disposal [19]. The euhedral crystals of portlandite $\left(\mathrm{Ca}(\mathrm{OH})_{2}\right)$ and gypsum $\left(\mathrm{CaSO}_{4} \cdot 2 \mathrm{H}_{2} \mathrm{O}\right)$ with well-outlined hexagonal and prismatic morphology, respectively, were also observed at SEM images (Figure 3). The crystals of both phases grew to several microns and were embedded in fine-crystal cement composed of mostly calcite $\left(\mathrm{CaCO}_{3}\right)$ (Figure 3). 
a)

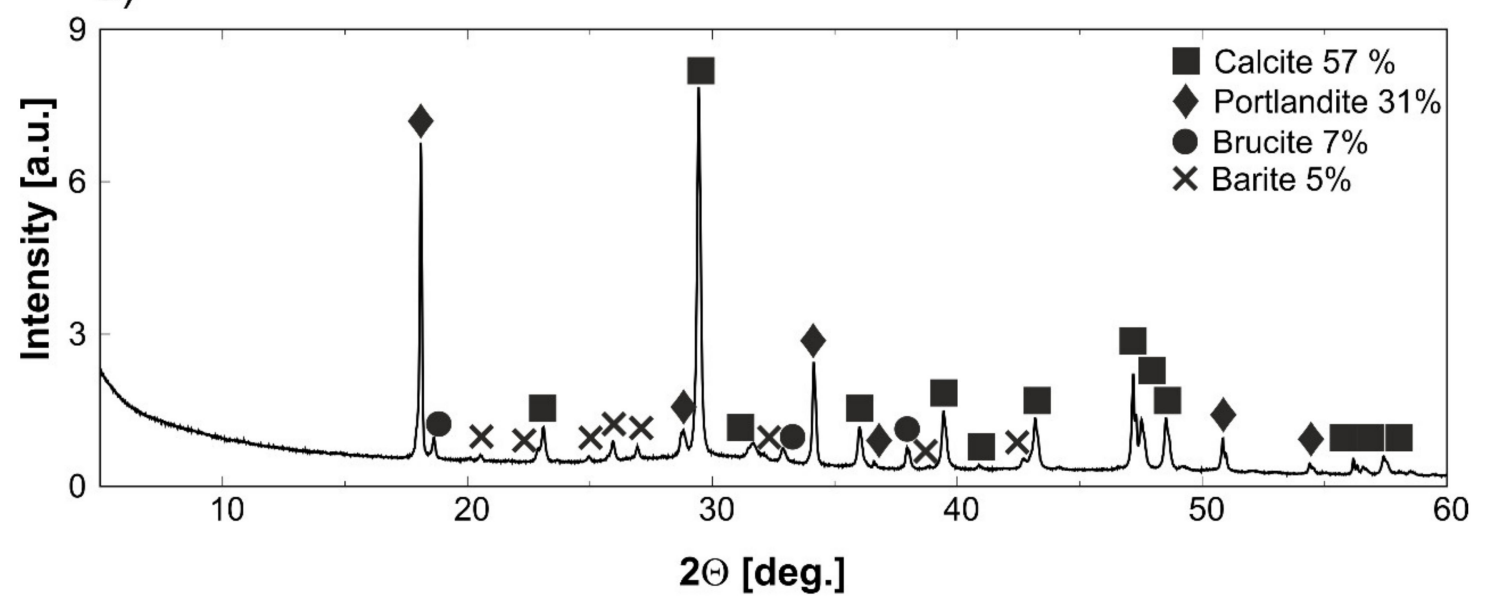

b)

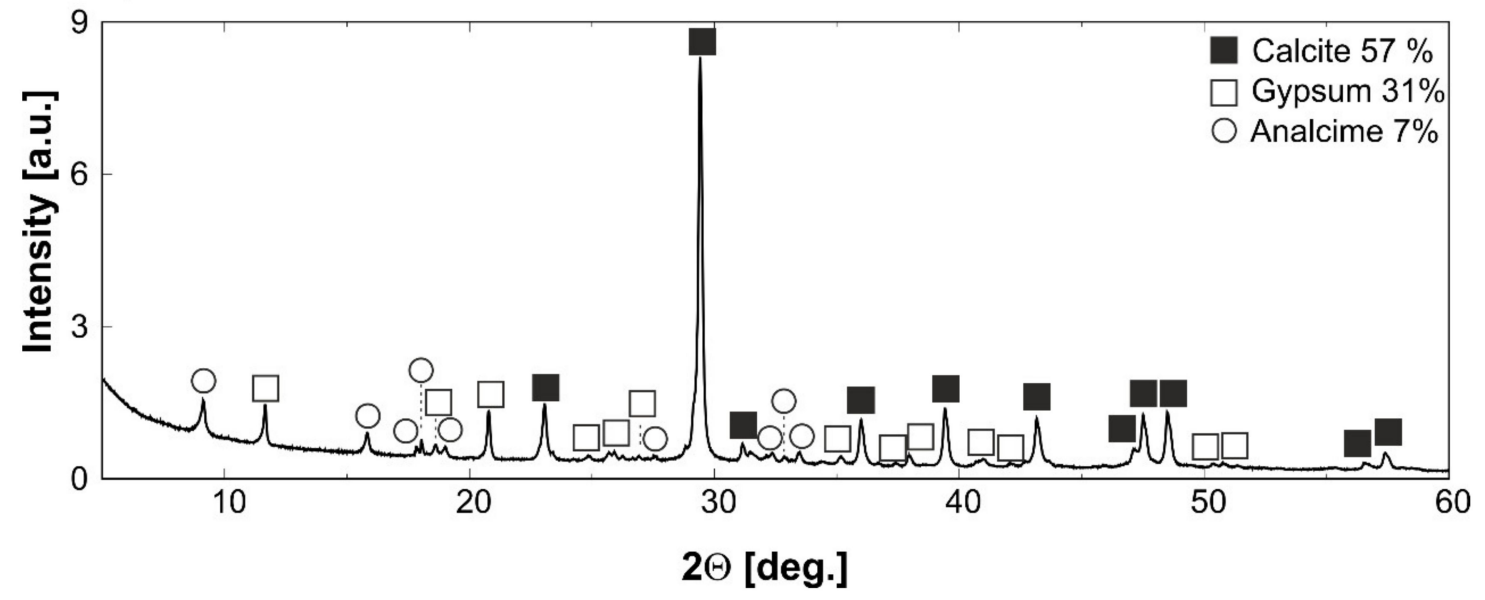

Figure 2. X-ray diffractograms and mineral compositions of two phases were found in the sample: the white cement (a) and the embedded grey inclusions (b).
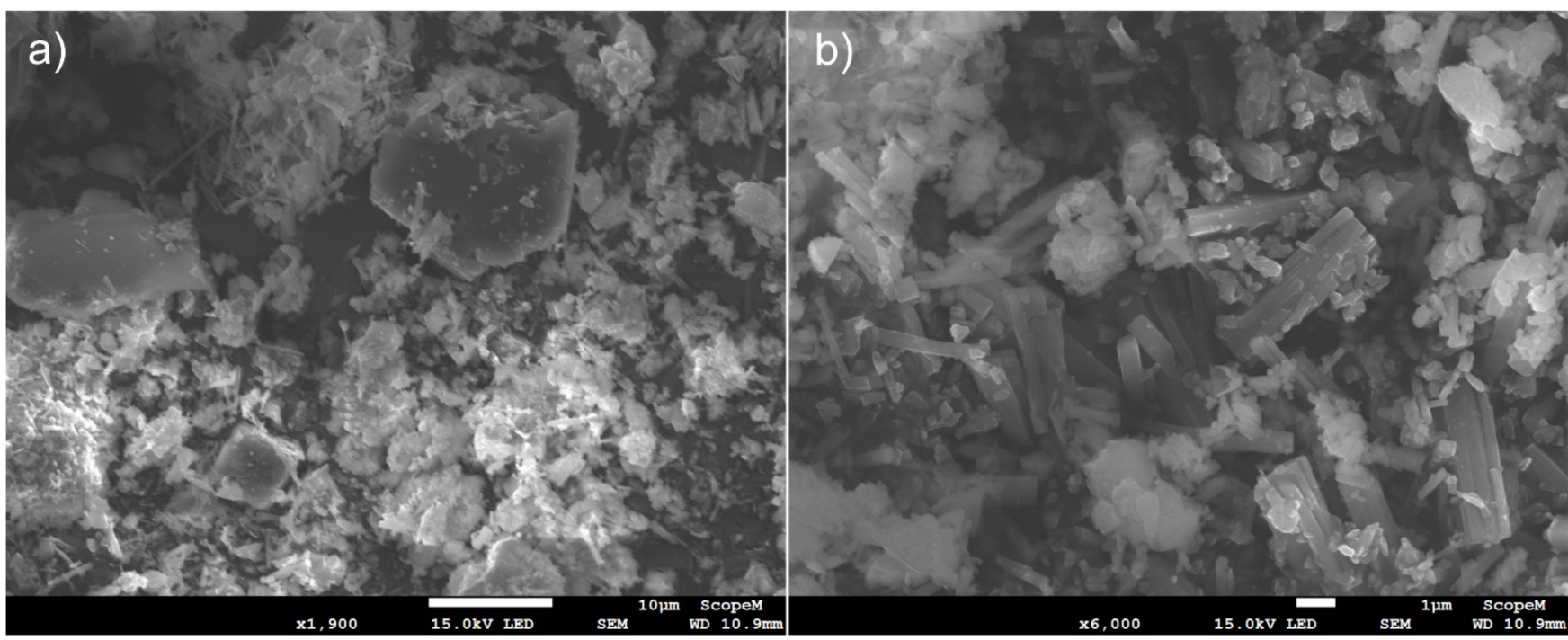

Figure 3. SEM images collected from the white cement (a) and the grey inclusions (b). Large crystals of portlandite (a) and gypsum (b) are surrounded by the fine grains of calcite. 


\subsection{Drained Triaxial Tests}

\subsubsection{Stress-Strain Behaviour}

The substantial differences between samples were the initial bulk density, initial level of compaction, apparent cementation, initial void ratio, and natural water content. Higher initial physical parameters are typical for samples collected from the first layer of ASR. The full stress-strain characterisation was conducted in the range from $0.2 \%$ to $35 \%$ (for samples collected from a depth of $8 \mathrm{~m}$ ) and up to $30 \%$ (for samples from a depth of $16.5 \mathrm{~m}$ ). Cauchy stress was used according to Equations (1) and (2) to calculate the mean effective stress $\left(p^{\prime}\right)$ and deviator stress $(q)$ :

$$
\begin{gathered}
p^{\prime}=\frac{\sigma_{1}^{\prime}+2 \sigma_{3}^{\prime}}{3} \\
q=\sigma_{1}^{\prime}-\sigma_{3}^{\prime}
\end{gathered}
$$

where $\sigma_{1}^{\prime}$ is the effective principal stress, and $\sigma_{3}^{\prime}$ is the effective confining stress.

The deviator stress versus axial strain curves are shown in Figure 4. As one can see in Figure $4 a$, the samples from the smaller depth (ASR I) led to strain-hardening behaviour at high confining pressures.

a)

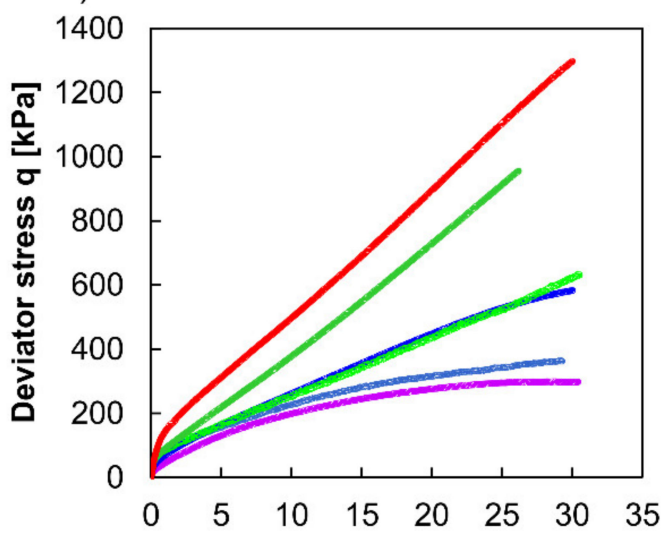

c)

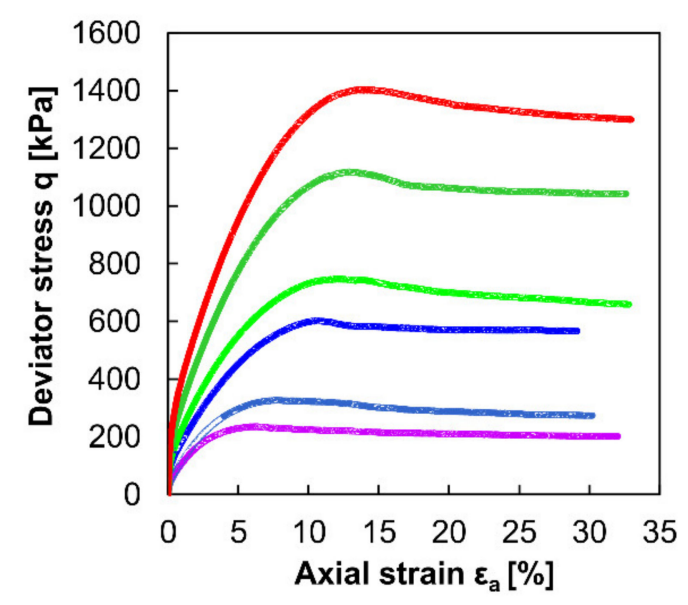

b)
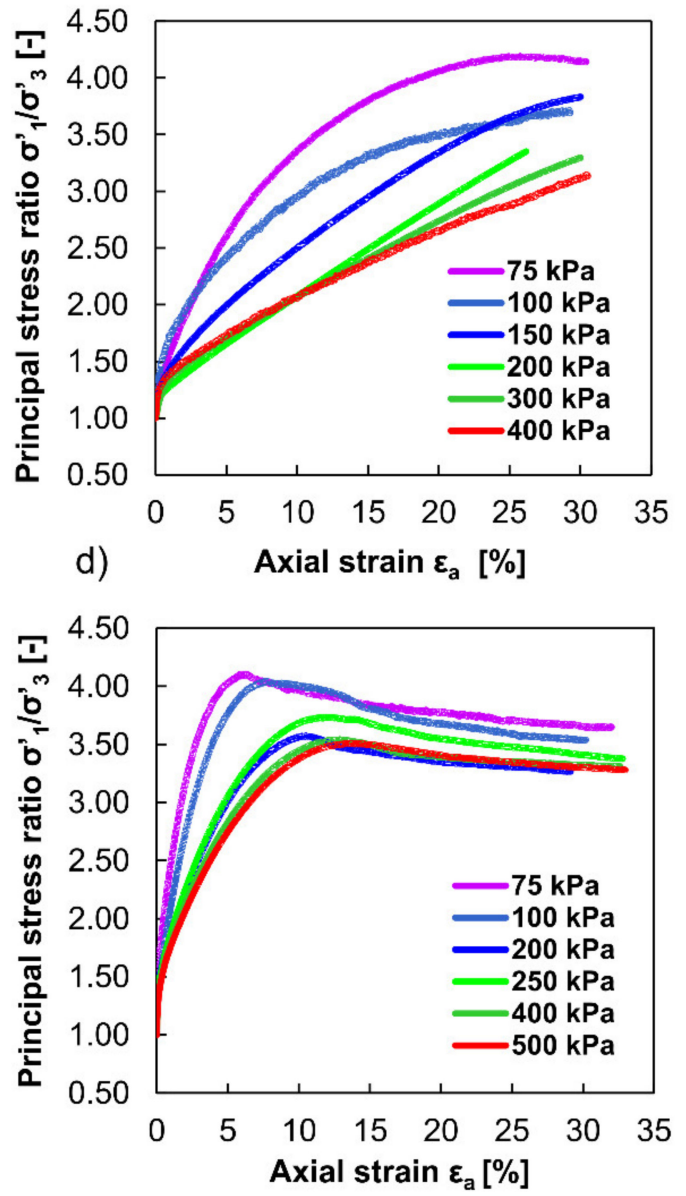

Figure 4. Drained triaxial test results: (a) axial strain $\varepsilon_{\mathrm{a}}$ vs. deviator stress $\mathrm{q}$ (ASR I), (b) axial strain $\varepsilon_{\mathrm{a}}$ vs. principal stress ratio $\sigma_{1}^{\prime} / \sigma_{3}^{\prime}$ (ASR I), (c) axial strain $\varepsilon_{a}$ vs. deviator stress q (ASR II), and (d) axial strain $\varepsilon_{\mathrm{a}}$ vs. principal stress ratio $\sigma_{1}^{\prime} / \sigma_{3}^{\prime}$ (ASR II).

In this case, the deviator stress was gradually increased with the simultaneous increase of axial strain. No distinct failure or any tendency to rupture even up to $30 \%$ axial strain was observed. Such behaviour is typical for loose sands and is represented by a monotonically increasing curve (Figure 4a) with no clear drops and, therefore, no pronounced peaks (the 
failure points). The increasing strength of ASR I with the higher confining pressure probably comes from the cementation bonds among soil particles caused by the inclusions consisting of fine calcite. Moreover, the ASR may have greater stiffness due to the interlocking of particles and densification. When the confining pressure is high, the voids in the ASR closed quickly, and dislocations become blocked. It is also favoured by the considerable amount of water that drained from the sample during the consolidation stage, bringing the grains closer together and reducing porosity. At low confining pressure (i.e., $\sigma_{3}^{\prime}=75 \mathrm{kPa}$ ), the stress-strain curve showed a specific weak strain-softening. From the practical point of view, it is appropriate to consider the peak value of the deviator stress as the failure criterion. None of the specimens from layer I could be taken as failure as defined by the Mohr-Coulomb criterion. The maximum values of the deviator stress were identified after $25 \%$ of the axial strain was exceeded. Hence, as the criterion of the failure, $20 \%$ of the axial strain was accepted. Moreover, the high values of the ultimate axial deformation for the discussed case may be associated with the low consolidation of the specimen and the weak microstructure (no bonds) of the material [44].

Figure $4 \mathrm{c}$ shows deviator stress versus axial strain curves for the samples from the greater depth (ASR II). It can be noticed that the shear resistance of an ASR decreases with further shearing after the shear stress has reached its peak value. Hereafter, the slope of the deviator stress versus axial strain curve decreased to its residual value in an axial strain of about $30 \%$. This phenomenon is referred to as strain-softening. Such behaviour is commonly associated with dense sands.

Notwithstanding, some studies have established that the observed strain-softening is not a material response but merely a consequence of nonhomogeneous deformations caused by the frictions between the specimen and the top and bottom loading platens or by the initial non-uniformity of the specimens [45-47]. Wanatowski and Chu [48] discussed two types of strain-softening behaviour under plane-strain conditions. For medium-dense sand, strain-softening occurred due to shear bands, mainly due to boundary constraints. The mentioned analysis also revealed that strain-softening is caused by the loading mode adopted to conduct the test. It is more pronounced in the tests with the deformation controlled (DC) loading mode when specimens are sheared using a constant rate of vertical displacement. In this way, strain-softening observed in the ASR samples from a greater depth is associated with the shear bands rather than the material's intrinsic behaviour. One should note that the traces of strain localisation were clearly visible at the end of the test in all specimens. However, it should be remembered that the strain localisation as a prelude to failure is initiated much earlier during the shearing. The strain localisation may emerge well before the peak shear stress, mainly due to heterogeneity in the specimen [49] or around the peak shear stress [50].

For the ASR I, the values of the principal stress ratio $\sigma^{\prime}{ }_{1} / \sigma_{3}{ }_{3}$ for the low confining pressures increased approximately linearly from unity to $\sim 3.35$ over the axial strain range of $5 \%$ to $30 \%$ (Figure $4 \mathrm{~b}$ ). In contrast, the values of the principal stress ratio $\sigma_{1}^{\prime} / \sigma_{3}^{\prime}$ increased non-linearly from unity to $\sim 4.14$ over the axial strain range of $0 \%$ to $30 \%$, under higher confining pressures. The most pronounced non-linear specimen response was observed for the confining pressures of $\sigma_{3}^{\prime}=300$ and $400 \mathrm{kPa}$. On the other hand, the values of the principal stress ratio $\sigma_{1}^{\prime}{ }_{1} / \sigma_{3}^{\prime}$ calculated for ASR II increased non-linearly, reaching a peak and then decreasing slightly (Figure $4 \mathrm{~d}$ ).

As shown in Figure 4, ASR I and ASR II specimens exhibited strain hardening and strain-softening behaviour, respectively. The different strain behaviour was attributed to the fact that the ASR II specimens were denser than the ASR I specimens because the ASR II specimens were collected at a greater depth than the ASR I specimens.

\subsubsection{Failure Modes}

Figure 5 shows the typical failure modes for the ASR I and ASR II samples. There are no definite trends in the failure modes with respect to the confining pressure or type of ASR. The ASR I samples in the drained tests revealed, in general, the barrelling mode with 
the incomplete partially developed shear band or the single shear band pattern (Figure 5). For the ASR II samples, the barrelling mode with the " $\mathrm{X}$ " or " $\mathrm{V}$ " shear band pattern was observed (Figure 5). One can note that in most cases, the failure mode was a combination of the barrelling shape and shear plane. Wherein the shear band was not obvious, and barrelling was the predominant mode.
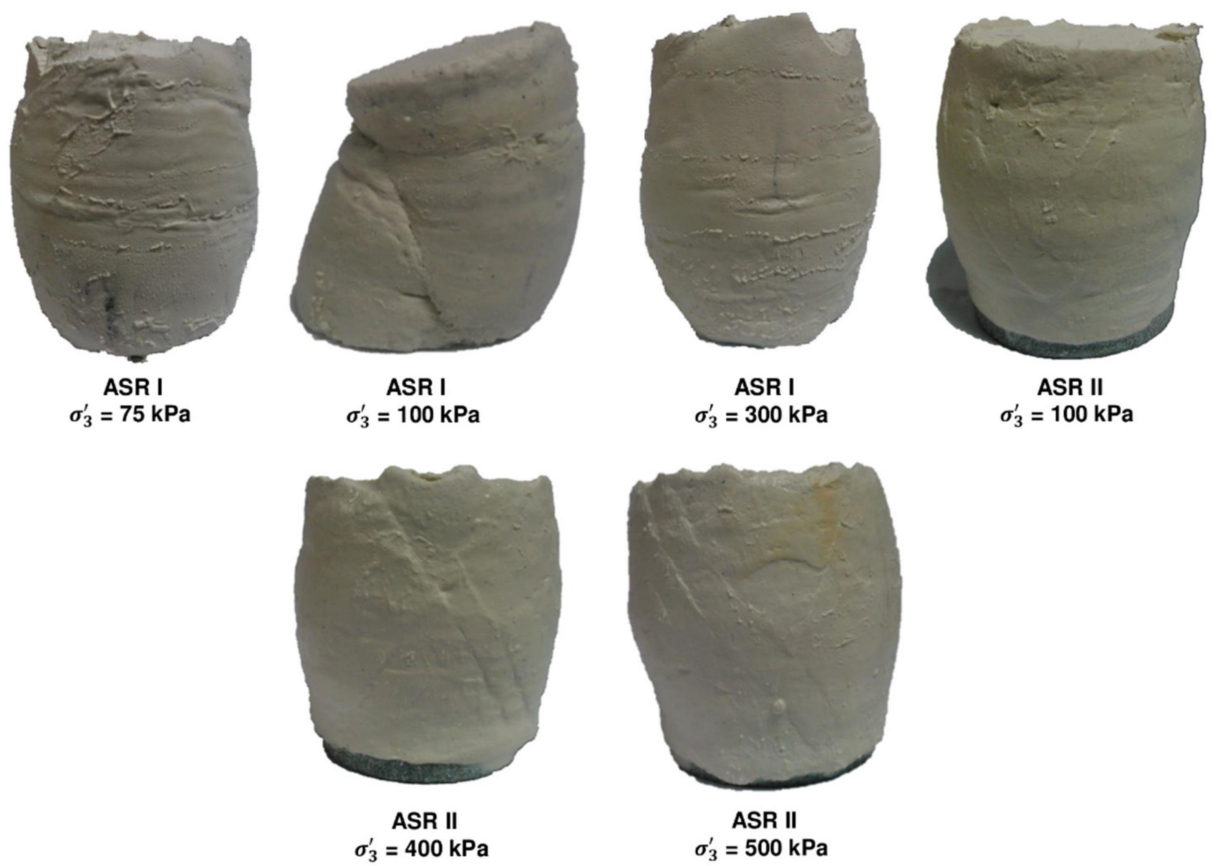

Figure 5. Typical failure modes of samples observed from the present study.

\subsubsection{Stress Paths}

The stress paths for two ASR are shown in Figure 6. The established failure and critical state lines are presented in the plots, defined by a line in the q-p' plane, with a slope of $\mathrm{M}$. The indices $\mathrm{p}$ and cs denote failure (peak strength) and the critical state, respectively. In particular, the critical state concept is the idea that soil and other granular materials, if continuously distorted until they flow as a frictional fluid, will come into a well-defined critical state [51].

a)

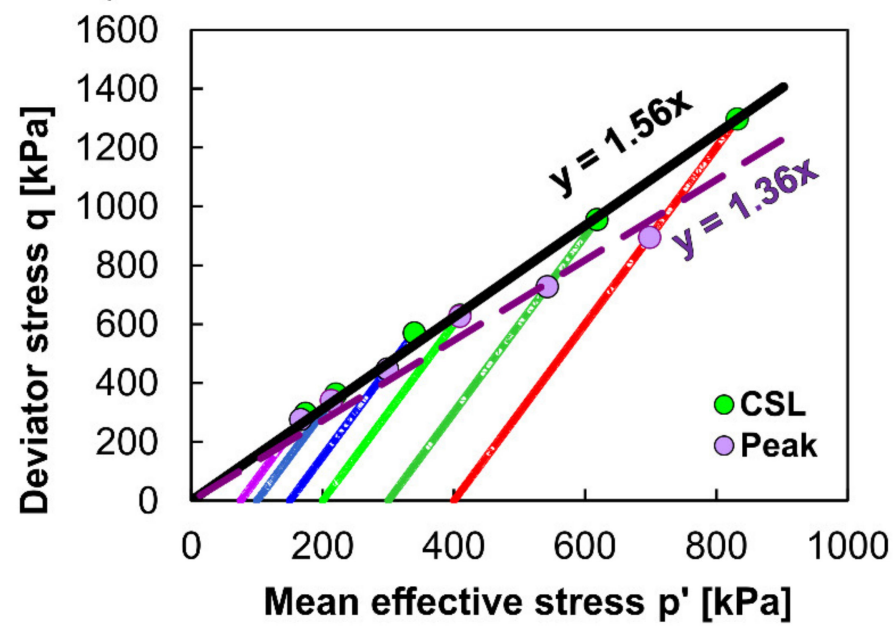

b)

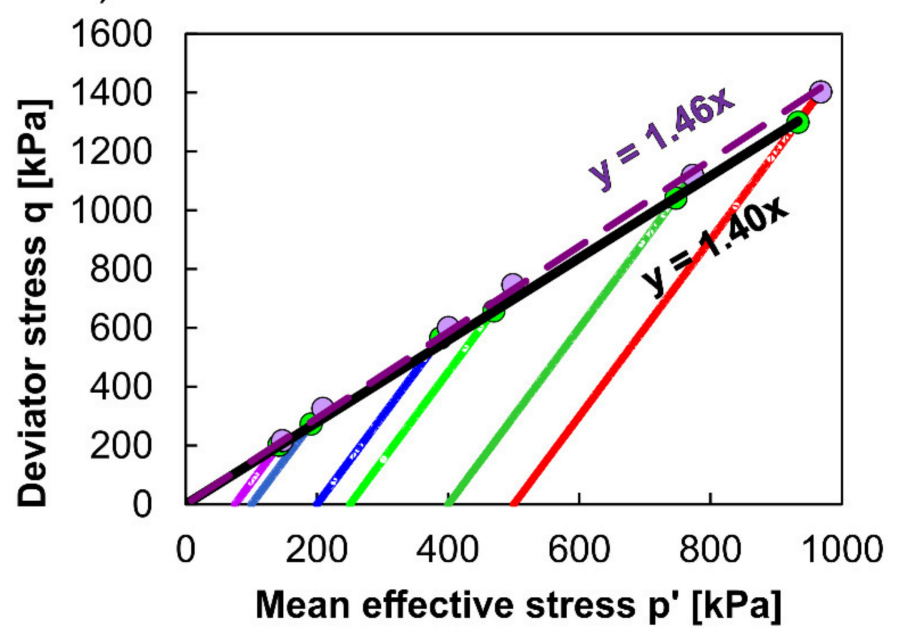

Figure 6. Effective stress paths in the drained triaxial compression tests with respect to the peak deviator stress and the critical state: (a) ASR I, (b) ASR II. 
The slope of the critical state line (CSL) is commonly called the critical state frictional constant $\mathrm{M}$ or critical state ratio and should be treated as a function of the intermediate principal stress, expressed by the lode angle $(\theta)$ [52]. Parameter $M$ defines the critical state stress ratio at failure conditions and is comparable to the critical friction angle $\left(\varphi^{\prime}{ }_{\mathrm{cs}}\right)$ for the Mohr-Coulomb failure line using the following expression:

$$
M=\frac{q}{p^{\prime}}=\frac{6 \sin \varphi_{c S}^{\prime}}{3-\sin \varphi_{c S}^{\prime}}
$$

Note that the correlation between $\mathrm{M}$ and $\varphi^{\prime}{ }_{\mathrm{cs}}$ is not unique but depends on the stress conditions [53], and Equation (3) is valid only for the compression case (i.e., when $\sigma_{\mathrm{a}}^{\prime}>\sigma_{\mathrm{r}}^{\prime}$ ). Figure 6 shows the stress paths for two ASRs. For the ASR I, the peak points of the stress path in the drained condition were lower than for ASR II over the whole range of confining pressures. The slope of critical state lines in the $\mathrm{q}-\mathrm{p}^{\prime}$ plane is $\mathrm{M}_{\mathrm{Cs}}=1.56$ and $\mathrm{M}_{\mathrm{f}}=1.36$ for ASR I. In turn, the values of $\mathrm{M}_{\mathrm{cs}}$ and $\mathrm{M}_{\mathrm{f}}$ for ASR II are 1.40 and 1.46, respectively. Overall, it can be seen that the data points drawn in Figure 6 can accurately be fitted by a linear function (one for failure and one for the critical state). In this regard, the failure locus and the critical state locus are independent of the drainage conditions.

Figure 7 shows Mohr stress circles drawn for the peak deviator stress or for the axial strain of $25 \%$ as obtained from the results of CD tests on ASR I and II. Note that the solid lines indicate the critical state, and the dashed lines the failure condition corresponding to the peak shear strength. These lines are tangent to the Mohr stress circles over the entire range of applied confining pressures (Figure 7). The values of effective cohesion, effective friction angles at peak $\varphi_{\mathrm{p}}^{\prime}$, and critical friction angles $\varphi_{\mathrm{cs}}^{\prime}$ for ASR I and ASR II (Figure 7) were comparable with the values for alluvial clayey silts [54] and many soft alluvial deltaic clays [55].
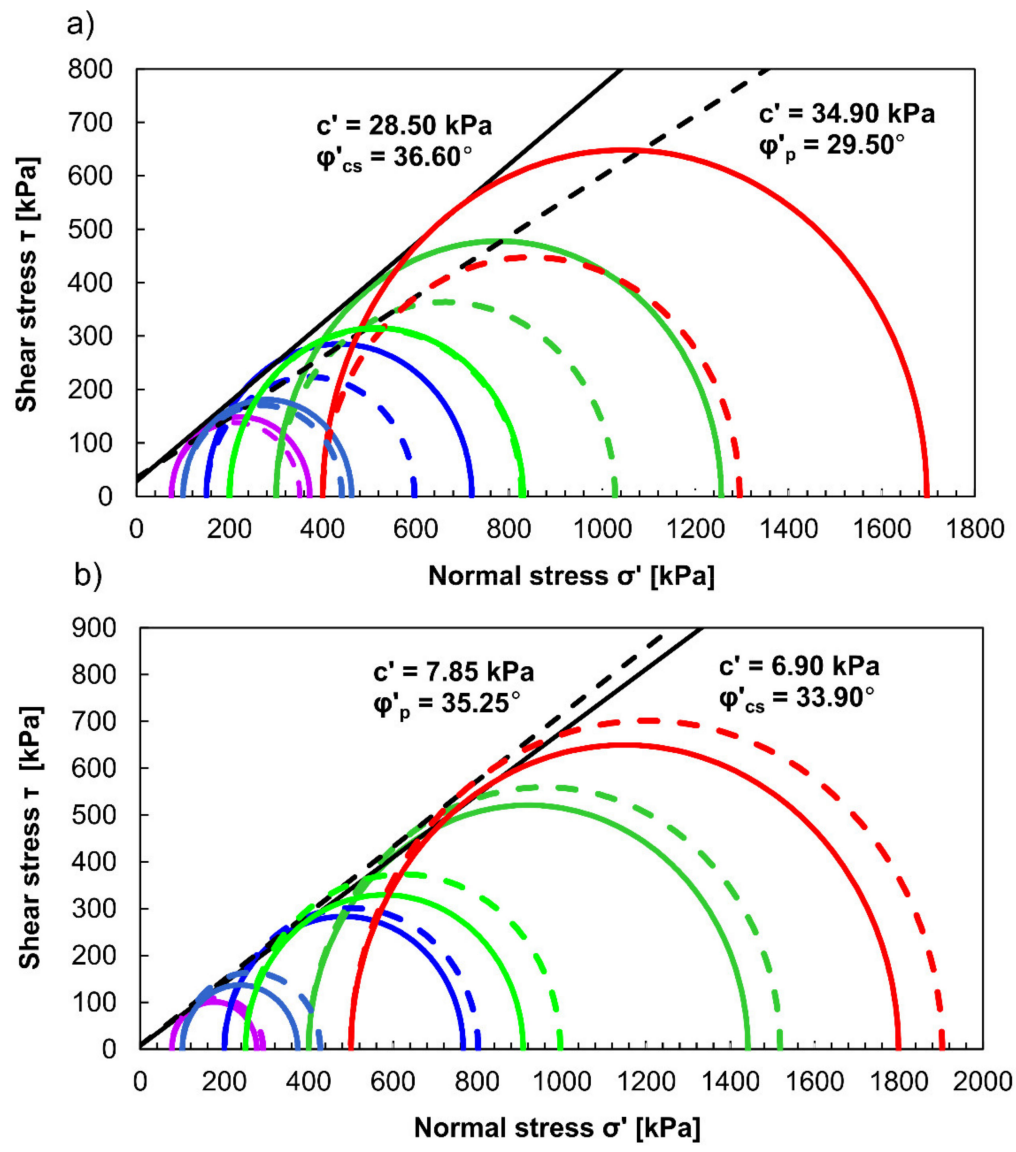

Figure 7. Mohr-Coulomb failure envelope based on the maximum deviator stress and the critical state from the drained triaxial tests: (a) ASR I, (b) ASR II. 
Moreover, the values of the effective friction angles from the present study were consistent with the reported numbers by $\mathrm{O}^{\prime}$ Kelly [56] for biosolids, sewage sludge, and water treatment residue materials. Considering the stability calculations for the intermediate and long-term conditions, the derived values are far too high for the design purposes.

\subsubsection{Stiffness}

The small-strain stiffness can be assessed by the tangential shear modulus $\left(\mathrm{G}_{\mathrm{sec}}\right)$ calculated using the relation between the deviator stress and deviator strain as follows:

$$
G_{s e c}=\frac{\delta q}{3 \delta \varepsilon_{s}}
$$

where $\delta_{\mathrm{q}}$ is the increment in deviator stress and $\varepsilon_{\mathrm{s}}$ is the increment in deviator strain.

The degradation of $G_{\text {sec }}$ with the deviator strain for different confining pressures is presented in Figure 8a. The stiffness of the ASR increases with the confining pressure. This trend is corroborated by the reported dependence of the normalised shear modulus and confining pressure $[57,58]$. The shape of the degradation curves varies slightly for the ASRs tested (Figure 8a). The typical S-curves were found in the most conducted tests. The samples of ASR I show the more gradual degradation of stiffness compared with the samples from ASR II. All tests, except the sample from ASR II under confining pressure of $500 \mathrm{kPa}$, indicate a threshold yield strain, which separates the plateau of the initial constant stiffness from the start of substantial stiffness degradation. Figure $8 \mathrm{~b}$ illustrates the variation of stiffness with the deviator stress for the considered confining pressures. The stiffness of ASR reduced with the deviator stress.

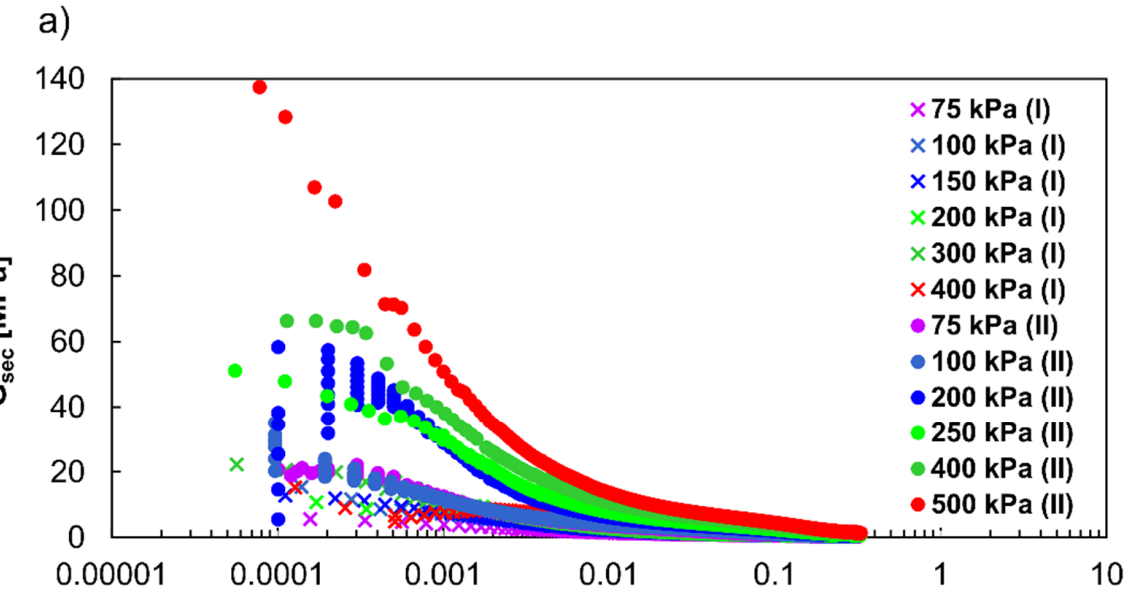
b)
$\varepsilon_{\mathrm{a}}=\varepsilon_{\mathrm{s}}[\%]$

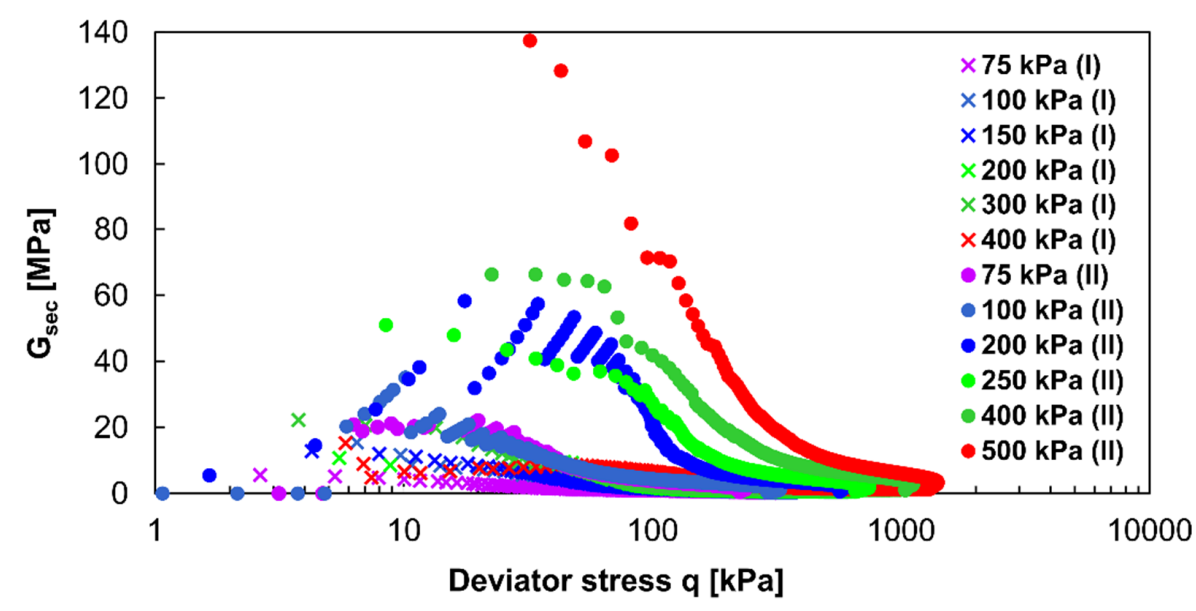

Figure 8. Small-strain stiffness of ASR: (a) deviator strain $\varepsilon_{\mathrm{s}}$ vs. tangential shear modulus $\mathrm{G}_{\mathrm{sec}}$, (b) deviator stress q vs. tangential shear modulus $\mathrm{G}_{\text {sec }}$. 


\subsection{Constant Rate of Strain Consolidation Tests}

During the CRS test, the vertical force $(P)$, axial strain, and pore pressure $\left(u_{b}\right)$ were measured continuously at the specified time intervals. The main problem with the interpretation of the CRS tests was a slight increase in the pore pressure at the sample bottom. The maximum increase in $\mathrm{u}_{\mathrm{b}}$ was only $2-3 \mathrm{kPa}$, hampering the determination of the coefficient of consolidation $c_{v}$ and the coefficient of permeability $k$. The lack of increase in $u_{b}$ was also independent of the assumed strain rate in the test. Figure 9 shows the obtained axial deformations as a function of the effective stresses $\varepsilon_{a}=f\left(\sigma^{\prime}\right)$. The analysis of the results revealed the relationship between the stress-strain behaviour during compression and the strain rate. As can be seen from Figure 9, the overall compressibility of the samples decreased with the increasing strain rate.

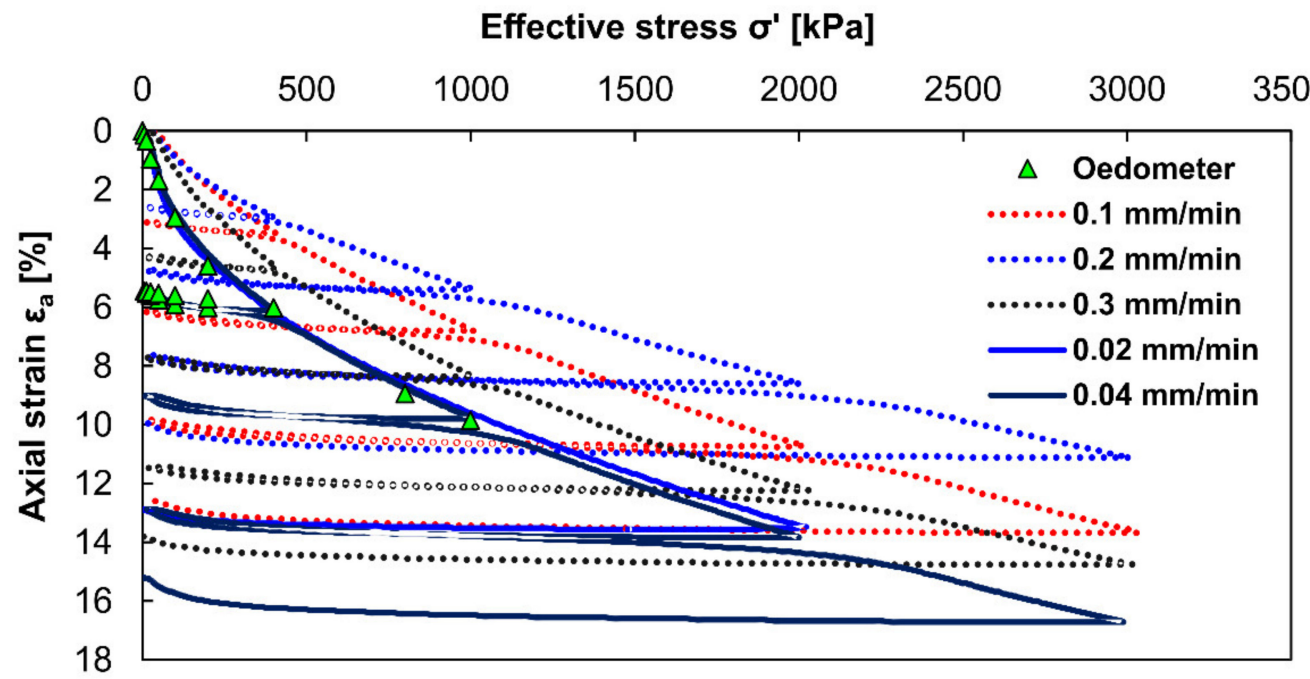

Figure 9. Compression curves for the different strain rates in CRS consolidation tests with superimposed data from the reference oedometer test.

The influence of the strain rate led to the proportional shift of the curve towards higher effective stresses (to the right). This effect was most pronounced at pressures around the yield stress. Using the graphic Casagrande method, the yield stress value of $155 \mathrm{kPa}$ was determined based on the oedometer test. Figure 9 also shows superimposed data from the reference oedometer test. The shape of the primary compression curves for the different strain rates was similar. It was observed that the curves from the CRS study shifted to the right, showing higher yield stress than in the oedometer study.

Moreover, it can be observed that for a given strain, the higher strain rate leads to higher effective stress. The strain rate values selected for the CRS test were generally higher than the observed strain rate in the oedometer test, which caused the compressibility curves derived from the CRS test to lie above the compression curve from the oedometer test. The compressibility curve for the CRS test, obtained with strain rate of $0.04 \mathrm{~mm} / \mathrm{min}$, was the closest to the oedometer curve. Therefore, an attempt was made to run the test at a value lower than the strain rate of $0.04 \mathrm{~mm} / \mathrm{min}$ to fit the results better. A new compression curve was obtained after taking the value of the strain rate of $0.005 \mathrm{~mm} / \mathrm{min}$ and performing the test. However, the expected curve shift to the left did not take place. On the contrary, the curve shifted to the right and was higher than the curve obtained with the $0.04 \mathrm{~mm} / \mathrm{min}$ strain rate. It should be remembered that the selection of very slow strain rates leads to the significantly extended test time, which may also cause the ageing effects and the gradual development of intermolecular bonds, which leads to an increase in preconsolidation pressure and a shift of the CRS compression curve to the right [59].

Additionally, in the course of the analysis, the compression index $\left(\mathrm{C}_{\mathrm{c}}\right)$ was calculated, which was 0.16 . This value indicates that ASR can be comparable with soils of a slight to low compressibility. 


\section{Conclusions}

In the study presented herein, the strength and compressibility of ammonia-soda residue from the Solvay Sodium Plant in Krakow were evaluated using triaxial compression tests and the constant rate of strain consolidation tests. The collected material for the laboratory testing was also characterised in terms of the mineral composition and microstructure. The results presented in this work can be summarised as follows:

1. Consolidated drained triaxial tests on the ASR reveal two different evolutions of the critical state in the stress-strain space. The strain-hardening behaviour when the deviator stress was gradually increased with the increase of axial strain without manifesting any distinct failure was observed for the ASR I. On the other hand, the stress-strain response of ASR II indicated strain-softening behaviour associated with the creation of the shear bands in the specimen.

2. The shear strength of ASR I and ASR II evaluated from the present study is similar to the data reported for the alluvial and deltaic soft fine-grained soils. The shear strength of ASR I and ASR II tested in this study for the case of the critical state is quantified to be $\mathrm{fi}=36.60$ and $\mathrm{fi}=33.90$, respectively. Effective cohesion for ASR I and ASR II can be best characterised by $\mathrm{c}^{\prime}=28.50 \mathrm{kPa}$ and $\mathrm{c}^{\prime}=6.90 \mathrm{kPa}$, respectively.

3. The determined strain rate in the CRS test significantly influences the stress generated in the ASR sample and, thus, the stress-strain response of the tested material. The optimal strain rate was successfully established using the results of the oedometric test. The results of the CRS test made it possible to obtain the compressibility index of the tested material. However, the slight increases in the pore pressure during the test hindered the determination of the $\mathrm{c}_{\mathrm{V}}$ and $\mathrm{k}$ parameters.

4. The X-ray diffraction results indicated that the main mineral components of the ASR are calcite and portlandite. The analysis of the SEM images showed that the ASR is a porous material made up of crystalline particles with a wide range of shapes and sizes.

Author Contributions: Conceptualisation, B.S.O.; methodology, B.S.O. and P.R.; validation, J.Z. and B.S.O.; formal analysis, B.S.O. and P.R.; investigation, B.S.O.; resources, J.Z.; data curation, B.S.O.; writing-original draft preparation, B.S.O.; writing—review and editing, B.S.O.; visualisation, B.S.O.; supervision, B.S.O. All authors have read and agreed to the published version of the manuscript.

Funding: This research received no external funding.

Institutional Review Board Statement: Not applicable.

Informed Consent Statement: Not applicable.

Data Availability Statement: The datasets generated during and/or analysed during the current study are available from the corresponding author on reasonable request.

Conflicts of Interest: The authors declare no conflict of interest.

\section{References}

1. Rui, Y.; Liang, Y.; Wang, Y. Wet simulation flue gas desulfurisation with soda-ash dregs absorbent. Environ. Sci. Technol. 2006, 29, 21-25.

2. Şener, S. Use of solid wastes of the soda ash plant as an adsorbent for the removal of anionic dyes: Equilibrium and kinetic studies. Chem. Eng. J. 2008, 138, 207-214. [CrossRef]

3. Jiang, S.; Zhang, Y.; Li, Z. A new industrial process of $\mathrm{NaHCO}_{3}$ and its crystallisation kinetics by using the common ion effect of $\mathrm{Na}_{2} \mathrm{CO}_{3}$. Chem. Eng. J. 2019, 360, 740-749. [CrossRef]

4. Pickles, C.A.; Togurib, J.M. Toguri Soda Ash Smelting of Lead Chloride. Can. Metall. Q. 1988, 27, 117-122. [CrossRef]

5. Pickles, C.A.; Togurib, J.M. The soda ash smelting of lead-acid battery residue. Resour. Conserv. Recycl. 1993, 9, 155-177. [CrossRef]

6. Allègre, C.; Moulin, P.; Maisseu, M.; Charbit, F. Treatment and reuse of reactive dyeing effluents. J. Membr. Sci. 2006, 269, 15-34. [CrossRef]

7. Ergas, S.J.; Therriault, B.M.; Reckhow, D.A. Evaluation of water reuse technologies for the textile industry. J. Environ. Eng. 2006, 132. [CrossRef]

8. Chu, K.Y.; Provost, J.R. The dyeing and printing of silk fabrics. Rev. Prog. Color. Relat. Top. 1987, 17, 23-28. [CrossRef]

9. Roberts, P. Soda ash for the glass industry. Glass Ceram. 1965, 22, 276. [CrossRef] 
10. Zeller, A.F. Soda Ash and the Glass Industry. In Proceedings of the 50th Conference on Glass Problems: Ceramic Engineering and Science Proceedings, Urbana, IL, USA, 7-8 November 1989; Wachtman, J.B., Ed.; American Ceramic Society: Westerville, OH, USA, 1990. [CrossRef]

11. Polkan, G.A.; Zavarina, S.V.; Gorokhovskii, V.A.; Pentko, V.L.; Bulanova, L.D.; Orlova, L.A.; Gorshkov, V.A. Soda Ash based on nepheline material used in the glass industry. Glass Ceram. 2003, 60, 208-212. [CrossRef]

12. Madeswaran, S.; Jayachandran, S. Sodium bicarbonate: A review and its uses in dentistry. Indian J. Dent. Res. 2018, 29, 672-677. [CrossRef]

13. Chazelas, E.; Deschasaux, M.; Srour, B.; Kesse-Guyot, E.; Julia, C.; Alles, B.; Druesne-Pecollo, N.; Galan, P.; Hercberg, S.; Latino-Martel, P.; et al. Food additives: Distribution and co-occurrence in 126,000 food products of the French market. Sci. Rep. 2020, 10, 3980. [CrossRef] [PubMed]

14. Wu, S.; Fitzpatrick, J.; Cronin, K.; Miao, S. Effect of sodium carbonate on the rehydration of milk protein isolate powder. Food Hydrocoll. 2020, 99, 105305. [CrossRef]

15. Statista. Available online: https://www.statista.com/statistics/587223/sodium-carbonate-production-worldwide (accessed on 9 August 2021).

16. Wotring, P.S.; Stadler, A.T. A field and laboratory investigation of ponded Solvay process residue behavior. In Proceedings of the Geo-Denver 2007: New Peaks in Geotechnics, Denver, CO, USA, 18-21 February 2007; American Society of Civil Engineers: Reston, VA, USA, 2007. [CrossRef]

17. Schmertmann, G.R.; Bachus, R.C. Geotechnical issues for closure of ammonia soda ash waste ponds. In Proceedings of the Conference from Research to Practice in Geotechnical Engineering, Geotechnical Special Publication 180, New Orleans, LA, USA, 9-12 March 2008.

18. Effler, S.W.; Matthews, D.A. Impacts of a soda ash facility on Onondaga Lake and the Seneca River, NY. Lake. Reserv. Manag. 2003, 19, 285-306. [CrossRef]

19. Kuang, S.P.; Zhang, C.J.; Jiang, Z.G.; Shi, Z.J. Review on comprehensive utilisation techniques of alkaline slag in soda ash factory. China Res. Com. Util. 2006, 3, 20-24. (In Chinese)

20. Zhang, G.; Li, X.; Li, Y.; Wu, T.; Sun, D.; Lu, F. Removal of anionic dyes from aqueous solution by leaching solutions of white mud. Desalination 2011, 274, 255-261. [CrossRef]

21. Yang, Y.B.; Zheng, M.R.; Guo, W.Y.; Wang, H.C. Experimental research on the durability of inorganic binder stabilised material with soda residue. Key Eng. Mater. 2014, 629-630, 189-194. [CrossRef]

22. Coleman, A.; O'Flaherty, M.M.; Davidson, D.T. Fly ash and sodium carbonate as additives to Soil-Cement Mixtures. In Proceedings of the 41st Annual Meeting of the Highway Research Board, Washington, DC, USA, 8-12 January 1962; pp. 108-123.

23. El-Rawi, N.M.; Toma, R.N. Investigation of the effect of some chemical additives on the strength of Iraqi soil-cement mixtures. J. Build. Res. Cen. 1987, 6, 1-12.

24. Sun, J.Y.; Gu, X. Engineering properties of the new non-clinker incorporating soda residue solidified soil. J. Build. Mater. 2014, 17, 1031-1035.

25. Zha, F.S.; Pan, D.D.; Xu, L.; Kang, B.; Yang, C.B.; Chu, C.F. Investigations on engineering properties of solidified/stabilised pb-contaminated soil based on alkaline residue. Adv. Civ. Eng. 2018, 2018, 8595419. [CrossRef]

26. He, J.; Wang, X. Shear strength of stabilised clay treated with soda residue and ground granulated blast furnace slag. J. Mater. Civ. Eng. 2019, 31, 06018029. [CrossRef]

27. Nazir, R.; Amiri, S.T.; Kassim, K.A. The effect of soda ash $\left(\mathrm{Na}_{2} \mathrm{Co}_{3}\right)$ on $\mathrm{pH}$ and compaction characteristics of Malaysian laterite soil. Electron. J. Geotech. Eng. 2013, 18, 2963-2968.

28. Han, S.; Wang, B.; Gutierrez, M.; Shan, Y.; Zhang, Y. Laboratory study on improvement of expansive soil by chemically induced calcium carbonate precipitation. Materials 2021, 14, 3372. [CrossRef] [PubMed]

29. Bai, X.; Ma, J.; Liu, J.; Zhang, M.; Yan, N.; Wang, Y. Field experimental investigation on filling the soda residue soil with liquid soda residue and liquid fly ash. Int. J. Damage Mech. 2020, 424. [CrossRef]

30. Ma, J.; Yan, N.; Zhang, M.; Liu, J.; Bai, X. Mechanical characteristics of soda residue soil incorporating different admixture: Reuse of soda residue. Sustainability 2020, 12, 5852. [CrossRef]

31. Wang, Q.; Li, J.; Yao, G.; Zhu, X.; Hu, S.; Qiu, J.; Chen, P.; Lyu, X. Characterisation of the mechanical properties and microcosmic mechanism of Portland cement prepared with soda residue. Constr. Build. Mater. 2020, 241, 7994. [CrossRef]

32. Shatov, A.A.; Dryamina, M.A.; Badertdinov, R.N. Potential utilisations of soda production wastes. Energy Sustain. Dev. 2004, 12, 565-571.

33. Kuznetsova, T.V.; Shatov, A.A.; Dryamina, M.A.; Badertdinov, R.N. Use of wastes from soda production to produce nonshrinking oil-well cement. Russ. J. Appl. Chem. 2005, 78, 698-701. [CrossRef]

34. Kesim, A.G. Properties of alinite cement produced by using soda sludge. Adv. Cem. Res. 2013, 25, 104-111. [CrossRef]

35. Yan, C.; Song, X.K.; Zhu, P.; Sun, H.Y.; Li, Y.P.; Zhang, J.F. Experimental study on strength characteristics of soda residue with high water content. Chin. J. Geotech. Eng. 2007, 29, 1683-1688.

36. Zhao, X.H.; Liu, C.Y.; Zuo, L.M.; Zhu, Q.; Ma, W.; Liu, Y. Preparation and characterisation of press-formed fly ash cement incorporating soda residue. Mater. Lett. 2020, 259, 126852. [CrossRef] 
37. Vincevica-Gaile, Z.; Teppand, T.; Kriipsalu, M.; Krievans, M.; Jani, Y.; Klavins, M.; Hendroko Setyobudi, R.; Grinfelde, I.; Rudovica, V.; Tamm, T.; et al. Towards sustainable soil stabilisation in peatlands: Secondary raw materials as an alternative. Sustainability 2021, 13, 6726. [CrossRef]

38. ISO 17892-4: 2016. Geotechnical Investigation and Testing_Laboratory Testing of Soil_Part 4: Determination of Particle Size Distribution; International Standardization Organization: Geneva, Switzerland, 2016.

39. ISO 17892-3: 2015. Geotechnical Investigation and Testing_Laboratory Testing of Soil-Part 3: Determination of Particle Density; International Standardization Organization: Geneva, Switzerland, 2015.

40. Zięba, J. Mechanical behaviour of calcareous waste under consolidated drained triaxial compression testing in saturated conditions. In Proceedings of the 5th International Scientific Conference on Civil Engineering-Infrastructure-Mining, Kraków, Poland, 17-18 January 2019. [CrossRef]

41. Leroueil, S.; Kabbaj, M.; Tavenas, F.; Bouchard, R. Stress-strain-strain rate relation for the compressibility of sensitive natural clays. Géotechnique 1985, 35, 159-180. [CrossRef]

42. Mesri, G.; Feng, T.W. Constant rate of strain consolidation testing of soft clays and fibrous peats. Can. Geotech. J. 2019, 56, 1526-1533. [CrossRef]

43. Ozer, A.T.; Lawton, E.C.; Bartlett, S.F. New method to determine proper strain rate for constant rate-of-strain consolidation tests. Can. Geotech. J. 2012, 49, 18-26. [CrossRef]

44. Leroueil, S.; Locat, J.; Vaunat, J.; Picarelli, L.; Faure, R. Geotechnical characterisation of slope movements. In Proceedings of the 7th International Symposium on Landslides, Trondheim, Norway, 17-21 June 1996; pp. 53-74.

45. Drescher, A.; Vardoulakis, I. Geometric softening in triaxial tests on granular material. Géotechnique 1982, 32, 291-303. [CrossRef]

46. Chu, J.; Lo, S. On the measurement of critical state parameters of dense granular soils. ASTM Geotech. Testing J. 1993, 16, 27-35. [CrossRef]

47. Chu, J.; Lo, S.; Lee, I. Strain softening behavior of a granular soil in strain path testing. J. Geotech. Eng. ASCE 1992, 118, 191-208. [CrossRef]

48. Wanatowski, D.; Chu, J. Drained behaviour of Changi sand in triaxial and plane-strain compression. Geomech. Geoengin. 2007, 2, 29-39. [CrossRef]

49. Thakur, V. Strain Localisation in Sensitive Soft Clays. Ph.D. Thesis, Norwegian University of Science and Technology, Trondheim, Norway, 2007.

50. Cheng, Z.; Wang, J. Quantification of the strain field of sands based on X-ray micro-tomography: A comparison between a grid-based method and a mesh-based method. Powder Technol. 2019, 244, 314-334. [CrossRef]

51. Ghafghazi, M.; Shuttle, D.A. Accurate determination of the critical state friction angle from triaxial tests. In Proceedings of the 59th Canadian Geotechnical Conference, Vancouver, BC, Canada, 1-4 October 2006; Canadian Geotechnical Society: Vancouver, BC, Canada, 2006; pp. 278-284.

52. Sadrekarimi, A.; Olson, S. Critical state friction angle of sands. Géotechnique 2011, 61, 771-783. [CrossRef]

53. Roscoe, K.H.; Schofield, A.N.; Wroth, C.P. On the yielding of soils. Géotechnique 1958, 8, 22-53. [CrossRef]

54. Powell, J.; Lunne, T. Use of CPTU data in clays/fine grained soils. Stud. Geotech. Mech. 2005, 27, 29-65.

55. Ouyang, Z.; Mayne, P.W. Effective friction angle of clays and silts from piezocone penetration tests. Can. Geotech. J. 2018, 55. [CrossRef]

56. O'Kelly, B.C. Geotechnics of municipal sludges and residues for land-filling. Geotech. Res. 2016, 3, 148-179. [CrossRef]

57. Ishibashi, I.; Zhang, X. Unified dynamic shear moduli and damping ratios of sand and clay. Soils Found. 1993, 33, 182-191. [CrossRef]

58. Darendeli, M.B. Development of a New Family of Normalised Modulus Reduction and Material Damping Curves. Ph.D. Thesis, University of Texas at Austin, Austin, TX, USA, 2001.

59. Qiao, Y.; Ferrari, A.; Laloui, L.; Ding, W. Nonstationary flow surface theory for modeling the viscoplastic behaviors of soils. Comput. Geotech. 2016, 76, 105-119. [CrossRef] 